\title{
Exodus of Healthcare Professionals: Antecedents of Occupational Turnover Among Nurses in Kenya
}

Sang J. Carolyn, Newa O. Fred, Murei Sally, Aruasa, Wilson

To Link this Article: http://dx.doi.org/10.6007/IJARBSS/v11-i2/8126

DOI:10.6007/IJARBSS/v11-i2/8126

Received: 07 January 2021, Revised: 31 January 2021, Accepted: 16 February 2021

Published Online: 27 February 2021

In-Text Citation: (Carolyn et al., 2021)

To Cite this Article: Carolyn, S. J., Fred, N. O., Sally, M., \& Aruasa, W. (2021). Exodus of Healthcare Professionals: Antecedents of Occupational Turnover Among Nurses in Kenya. International Journal of Academic Research in Business and Social Sciences, 11(2), 695-716.

Copyright: (c) 2021 The Author(s)

Published by Human Resource Management Academic Research Society (www.hrmars.com)

This article is published under the Creative Commons Attribution (CC BY 4.0) license. Anyone may reproduce, distribute, translate and create derivative works of this article (for both commercial and non-commercial purposes), subject to full attribution to the original publication and authors. The full terms of this license may be seen at: http://creativecommons.org/licences/by/4.0/legalcode

Vol. 11, No. 2, 2021, Pg. 695 - 716

Full Terms \& Conditions of access and use can be found at http://hrmars.com/index.php/pages/detail/publication-ethics 


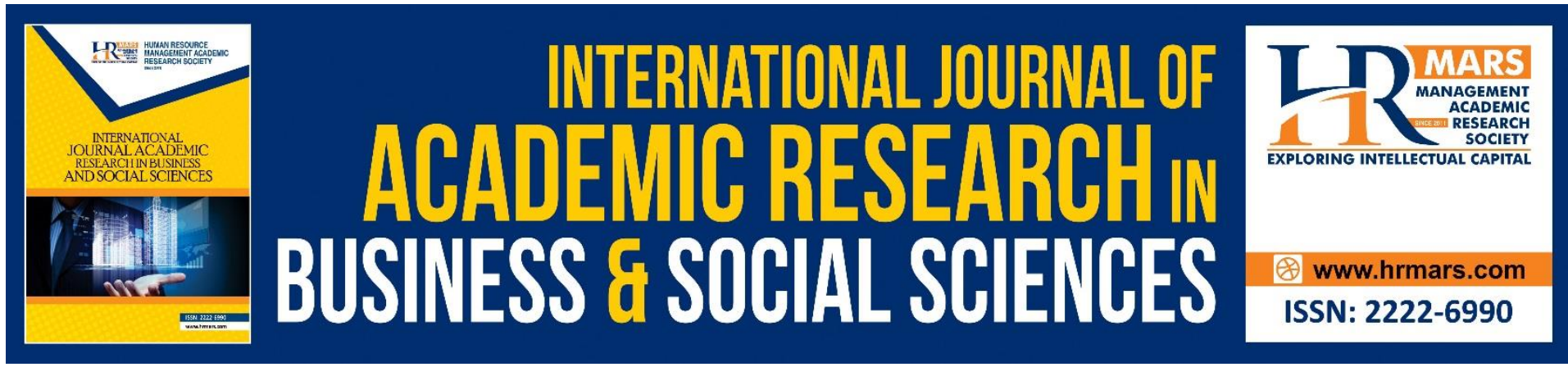

\title{
Exodus of Healthcare Professionals: Antecedents of Occupational Turnover Among Nurses in Kenya
}

\author{
Sang J. Carolyn \\ Deputy Director-Nursing Services, Moi Teaching \& Referral Hospital (MTRH), P.O. Box 3- \\ 30100 Eldoret, Kenya \\ Email: karolsang@gmail.com
}

Newa O. Fred

Lecturer, International Business Administration, United States International UniversityAfrica, Chandaria School of Business, P. O. Box 14634 00800, Nairobi, Kenya

Email: fnewa@usiu.ac.ke

\section{Murei Sally}

Assistant Lecturer, School of Nursing \& Midwifery, College of Health Sciences Moi University, P.O. Box 4606-30100, Eldoret, Kenya

Email: Smurei2001@gmail.com

\section{Aruasa, Wilson}

Chief Executive Officer, Moi Teaching \& Referral Hospital (MTRH), P.O. Box 3-30100 Eldoret, Kenya

Email: aruasaw@gmail.com

\begin{abstract}
Background: Despite the strides made in the healthcare sector in Kenya, the country is still bedevilled by nurses' shortage arising from high turnover rates particularly in public hospitals. The purpose of this study is to investigate the factors contributing to occupational turnover among nurses in Kenya. Methods: Descriptive research design, was used to collect data from 274 nurses using a questionnaire-based survey on the basis of systematic random sampling technique. Results: The overall correlation results showed that those who were dissatisfied with working conditions were more likely to have intent to leave $(r=.391, p<0.001)$. Further, findings revealed that those who felt dissatisfied with the training and development policies were more likely to have intention to leave $(r=.398, p<0.001)$. It was also established that those who felt dissatisfied with pay and benefits were more likely to have intention to leave $(r=.513, p<0.001)$. Finally, the study established that those who felt dissatisfied with the way management support to staff, were more likely to have intention to leave MTRH ( $r=.493$, $p<0.001)$. Practical Implications: The need to reduce turnover rates among nurses remains paramount. Unless sufficient numbers of nurses are recruited and retained within the nursing profession, provision of quality health care services and patient care will be hampered. Thus,
\end{abstract}


hospital management should devise effective strategies to curb the rising turnover rates among healthcare workers. Conclusion: Turnover among healthcare professionals has been attributed to discontent with work related factors. Hospital management could create and maintain a healthy environment with resources that nurses need to use during the provision of care, address the effects of the staff turnover.

Keywords: Turnover, Job Satisfaction, Quality healthcare, Health Professional, Nursing Profession

\section{Introduction}

Employees are the most important resource in the healthcare systems. Nurses form the largest percentage of workers in hospitals, and they are at the frontline of providing medical services to the public. The correlation between the availability of health workers and coverage of health interventions suggests that the public's health suffers when health workers are scarce (Sousa et al., 2006). This raises the more fundamental issue of whether there are enough health workers. A major factor underlying these shortages is turnover. Although the definition of turnover varies according to different literature, employee turnover is defined as the ratio of the number of workers that had to be replaced in a given time period to the average number of workers and generally viewed as the movement of staff out of an organization (Coomber \& Barriball, 2007). In the context of this study, it refers to the rate at which the healthcare organization gains or loses nurses over a certain period of time.

In the recent past, the nursing profession has witnessed a worrying trend in nurse turnover. The global healthcare workforce index indicate that over $40 \%$ of all countries have fewer than 10 medical doctors per 10000 people, over $55 \%$ have fewer than 40 nursing and midwifery personnel per 10000 people, over $68 \%$ have fewer than five dentists per 10000 population and over $65 \%$ have less than five pharmacists per 10000 population (World Health Organization, 2019). Extant empirical reviews (Dewanto \& Wardhani, 2018; Hung \& Lam, 2020) note with concern that global turnover rate among nurses stands at between $15-44 \%$. This paints a gloomy picture in the nursing profession and claws back the gains made in the provision of quality nursing care. In the USA for instance, a study undertaken at different times, the national turnover rate for hospital nurses was $12 \%$ in $1996,15 \%$ in 1999 , and $26.2 \%$ in 2000 (Shader et al., 2001). The annual turnover rate in the nursing workforce is higher than the turnover rates in any other profession, reaching between 9 and 15\% in Germany, Italy, Finland, France, and the UK (Estryn-Behar et al., 2007). Among nurses under the age of 30 in Germany, Canada, the USA, England, and Scotland, 27-54\% reported plans to leave their positions within the coming 12 months (Aiken et al., 2001). The increase in nurse turnover has been met with a decrease in enrolment in nursing educational programmes in several countries. It has been reported that the number of students enrolled in nursing schools in Australia has decreased by $11 \%$ during the 1990 s and is also expected to decrease worldwide (Cowin, 2002).

A study similarly found that $17,30,39$, and $23 \%$ of nurses intended to leave their current job in the next year in Germany, Scotland, England, and the USA, respectively (Aiken et al., 2001). Increase in nurse turnover can widen the patient-to-nurse ratio, therefore adding to the nurses' workload. Increasing nurses' workload may lead to a deterioration in the quality of care delivery hence affecting patient satisfaction and health care outcomes (Jones, 2004). The increase in nurse turnover has been met with a decrease in enrolment in nursing educational programmes in several countries. It has been reported that the number of students enrolled 
in nursing schools in Australia has decreased by $11 \%$ during the 1990s and is also expected to decrease worldwide (Cowin, 2002). In recent years, the situation of human resources for health ( $\mathrm{HRH}$ ) in many sub-Saharan African countries has been commonly described as "the crisis in human resources for health" (Liese \& Dussault, 2004). While Sub-Saharan Africa carries over $24 \%$ of the global burden of disease, only $3 \%$ of the global health workforce works in this region. The resulting gap between supply (in terms of healthcare workforce) and demand (for health services) results in inability to give proper attention to each client and provide care as needed (Anyangwe \& Mtonga, 2007; Gerein, Green, \& Pearson, 2006). SubSaharan countries struggle to cope with these negative consequences and to deliver minimum standards of healthcare (Naicker, Plange-Rhule, Tutt, \& Eastwood, 2009). This threatens the ability to accomplish health-related Sustainable Development Goals, particularly in ensuring healthy lives and promoting well-being for all [4]. Each further decrease in the number of healthcare employees brings further negative health consequences (Gerein et al., 2006; Shader et al., 2001).

The challenge of nurses' shortage as a result of high turnover in Kenya has been exacerbated by the devolution of the healthcare system and the roll out of the universal health care program in December, 2018. Currently, the nurse: patient ratio in Kenya stands at 25:10,000 against the WHO recommended ratio of 83:10000 (World Health Organization, 2019). The government of Kenya has recognized that the emergence and re-emergence of infectious diseases such as HIV/AIDS, TB and malaria have increased the demand for health services, putting an additional stress on the existing human resources in the public health sector. Prevalence of HIV/AIDS in Kenya remains one of the highest in the region, at $4.9 \%$ in 2019 (Ministry of Health, 2018). As Kenya started receiving support for HIV/AIDS, TB, malaria and immunization services from international donors such as PEPFAR, GFATM and GAVI in $2004-$ 2005 , the country's ability to translate such funding into improved and equitable health outcomes was threatened by the lack of sufficient human resources in the health sector(Chankova, Muchiri, \& Kombe, 2009). From the aforementioned, it is clear that many empirical studies have been conducted. The findings of most of these reviews however have been inconsistent and inconclusive on the factors associated with high turnover rates among nurses in Kenya. Furthermore, most of these studies have been undertaken in the Western world. Very few studies within the Kenyan context exist particularly in reference to nurses. Thus, the objective of this study was:

- To investigate the antecedents of occupational turnover among Nurses in Kenya with specific reference to Moi Teaching and Referral Hospital (MTRH), the second largest referral hospital in Kenya.

\section{Theoretical and Hypothesis Development}

This research was anchored on the Unfolding Theory of Turnover. This theory builds upon Beach (1998) Image Theory. The Unfolding Theory of Turnover proposes that employees follow one of five cognitive pathways when making the decision whether to quit a certain job (Lee \& Mitchell, 1994). A cognitive pathway refers to how employees interpret their work environment, identify options, and enact responses. Lee and Mitchell (1994) propounded that if an employee's system was shocked, it would trigger a psychological decision-making process that may lead to a job quit. Shocks were said to be particular events that would happen to someone. It would make one reassess the commitment to the organization, the ability to achieve the personal goals if they stayed on, and if they could be attached and committed to another organization. This then determined whether one was going to stay or 
leave an organization. according to (Beach, 1998), quoted in Lee and Mitchell (1994), the image theory incorporates rational choice theory. Beach (1998) asserted that in real decision processes, their assumptions are contrary to the prevailing view of classical decision theory. They argued that "screening" rather than "choosing" among options is the most important mechanism for understanding decisions. Beach (1998) further stated that screening is rapid and crude process of integrating information into three domain specific images: namely, values, which incorporate decision maker's principles, trajectory, which incorporates desired goals, and strategies, which consider how to achieve those goals. Choices are adapted or rejected depending on fitting with subsets of images (Morrell et al., 2008).

Morrell et al. (2008) stated that a shock is a specific event that prompts people to consider leaving employment in an organisation. Lee and Mitchell (1994) theorised that "it is a distinguishable event that jars employees towards deliberate judgements about their jobs and, perhaps, to voluntarily quit their jobs". They state that a shock is information generating and meaningful. They also caution that not all events can be shocks. Furthermore, Lee and Mitchell (1994) described a script as a "pre-existing plan of action and as routinised behaviour. Decision paths as explained by the theory shows how people leave in different and distinct ways represented by mutually exclusive decision paths.

\section{Literature Review}

Health professionals who remain to work in the public system are facing heavy workloads due to the combined burden of infectious and chronic diseases, particularly related to HIV/AIDS (Chen et al., 2004; Dovlo, 2005). The result of this situation is a workforce that is increasingly demoralised, stressed and dissatisfied. Many international studies have investigated the reasons why nurses leave work (Cartledge, 2001; Nguyen et al., 2008; Shader et al., 2001). According to these studies, multiple factors contribute to nurses' decision to leave; these factors relate to work stress, low salaries, desire for professional development and the lack of respect and recognition by society. Other factors included dissatisfaction with the supervisor, inflexible schedules, desire to work in a different field, high workload and family reasons (Shader et al., 2001). It was also reported that the likelihood of unsatisfied nurses to leave the profession was $65 \%$ higher than satisfied nurses. Additionally, poor retention strategies can influence nurses' choice to leave the workforce (Shields \& Ward, 2001).

\section{Factors Associated with Nurses' Turnover}

Many international studies have investigated the reasons why nurses leave work(Cartledge, 2001; Nguyen et al., 2008; Shader et al., 2001). According to these studies, multiple factors contribute to nurses' decision to leave

\section{Working Conditions}

Workings conditions refer to the environmental aspects of the workplace and all the components influencing the Nurse ability to perform their job (Momanyi \& Kaimenyi, 2015). A positive working environment is a critical motivation factor for employees; it inspires the workers with a feeling of pride and appreciation to work under such prestigious conditions (Haider et al., 2015). On the other hand, negative working environments are characterized by stress, burnouts, and numerous risks that adversely affect the Nurse productivity and performance and eventually cause the professionals to leave their jobs (Madanayake, 2014). According to (Applebaum et al., 2010), nurses move from hospital to hospital in search of good working conditions. An attractive working environment acts as an incentive for the entry 
new nurse into the healthcare industry, and determines the Nurse commitment to an organization. Moreover, a favourable working condition creates an enabling environment for the efficient performance of employees through the provision of necessary physical resources, medical supplies, management, and social support (Deighan, 2016).

There are two dimensions of the working environment the physical and behavioural aspects. The physical components relate directly to the general infrastructure conditions of the workplace, and resources availability (Deighan, 2016). Various studies like Onyango (2016) establish a direct link between the physical working environment and employees' productivity. Modern equipment, good lighting, ventilation, and controlled temperature are the prerequisite of attractive workplaces (Skefales et al., 2014). In general, these elements have an impact on the attitude and behaviour of nurses which have a positive correlation with productivity.

\section{Physical Working Conditions}

A number of studies highlight the relationship between the physical working conditions and nurse turnover. McGuire and McLaren (2009) in their study on the effect of physical working environment and employee commitment in call centres highlighted two critical aspects of the working conditions. Foremost is the general conditions of the working environment, including cleanliness, design, quality equipment and work space and elevation of the surface area. These factors also impact nurse turnover as seen from other studies. Applebaum et al. (2010) Conducted a study to assess the impact of working environment on nurse turnover intention using a sample of 116 nurses. They found significant relationship between noise levels and stress, which ultimately leads to turnover. (Horiguchi et al., 2015) also found that perception of unpleasant nurse odours contributes to the development of work burnout and nurse turnover in Japanese hospitals. Nurses spent a majority of their time in the hospital, and were highly perceptive of the smells in the hospital rooms and nursing stations. odours perception affected the nurses emotionally by influencing their overall comfort in the working environment and higher stress levels. However, the study failed to take into consideration the size of the hospital and various rooms making it difficult to generalize the findings in the current study.

\section{Resource Adequacy}

Adequacy of resources significantly contributes to high nurse turnover (Rachiotis et al., 2014). (Rachiotis et al., 2014)surveyed 303 nurses to find the effect of inadequate medical supplies and burnout among nurses in Greece. In 2007, Greece suffered from an economic crisis that adversely affected the workforce, and the 2010 rescue plan from the European Union required the country to introduce radical changes in its operations including health 16 budget. Consequently, the country began to experience serious shortage of medical supplies, and nurses were forced to care for an increasing patient population within the limited resources. $88 \%$ of the study participants reported high emotional exhaustion attributed to the medical supplies in the country. However, it is notable that the study was conducted at a time when everybody in the country was experiencing tough financial conditions, and these problems could have affected the findings. Therefore, the results cannot be generalized to other countries. (Deighan, 2016) Concurs that adequate medical supplies have a significant influence on employee turnover. The author notes that employees are empowered by the availability of resources and tools to perform their duties; they also experience autonomy over their work. Failure to provide this type of support causes voluntary turnover. Noteworthy 
is the positive relationship between empowerment and motivation in the organization (Momanyi \& Kaimenyi, 2015). Ahmed and Waqas (2017) occupational injuries are associated with high employee turnover rates in high safety cultures. According to the authors, many developing countries like Pakistan have poor working environments that affect the physical, psychological, and mental wellbeing of workers negatively. Neglecting workers' safety leads to high intentions of turnover in the country. A major limitation in the study is unskilled labour force in the country; these people opt to stay in organizations irrespective of occupational injuries because of their high poverty rates. Fasanya and Dada (2016) established that there is a high prevalence of workplace violence in the nursing profession. Nurses are subject to physical and verbal abuse from patients, families, and colleagues within the hospital, and reports of these cases are often ignored by their supervisors. Lack of proper regulatory framework to detect WPV places the nurses at higher risks, and some may consider change of jobs. The findings are consistent with a study done on causes of nurses' turnover in public hospitals located in Limpopo, South Africa (Tshitangano, 2013). According to the study, $73 \%$ of the participants were dissatisfied with the safety measures in the workplace as they often experience assault and were exposed to dangerous chemical substances. Since Nurses operate under high-risk environment, it is critical for the management to establish the best safety standards to protect them from unnecessary stress (Ankomah, Kumah, \& Karikari, 2016).

\section{Organizational Behaviour}

Organizational behaviour is the second element of the working environment; it encompasses different aspects including the attitude, culture, communication practices, and values of personnel working in one entity (Skefales et al., 2014). The attitude and conduct of each 17 employee has a significant impact on the others, and affects the development of group cohesion (Momanyi \& Kaimenyi, 2015). Therefore, it is critical for the management to promote respect among the workers and ensure the responsible behaviour to facilitate the cooperation among the nurses. Besides, social belongingness is the second category of Maslow's Hierarchy of Needs, and a strong motivator (Onyango, 2016). Numerous studies highlight the positive relationship between working environment and job satisfaction. Various environmental factors like odour, noise, and colour lead to stress and low job satisfaction (Applebaum et al., 2010). Other vital physical attributes attributed to good working conditions are hospital layouts that inhibit quick and smooth movement of nurses and patients, hospital furniture, and ergonomics (Jagun, 2015; McHugh \& Ma, 2014).

\section{Methods}

\section{Design}

Descriptive research design was used in this study. This design provided a vivid and accurate picture of the study phenomenon and enabled the researcher achieve a thorough and better understanding of the phenomenon under investigation

\section{Participants}

This study used a sample size of 274 nurses. Selection of this sample from the nurses was guided by the systematic random sampling technique. The technique was appropriate for this study because it ensured that the selection of a representative sample of nurses in the hospital. Besides, systematic random sampling gives each person equal opportunity of being selected this is a probability technique and this led to low selection bias. A list of nurse's 
returns was used as the sampling frame the beginning number was chosen randomly and the interval was obtained by computing population size divided by the sample size, therefore every nth person was chosen to participate in the research. A list was generated based on the interval. The following inclusion and exclusion criteria were applied to the participants; Nurse population working fulltime in MTRH were included whereas those nurses who were on study leave, unpaid leave, and those who did not consent to participate in the study were excluded.

\section{Data Collection}

Primary data gathered through the use of questionnaires which contained structured and semi structured items was used to collect data from nurses at Moi Teaching and Referral Hospital (MTRH). Incorporation of semi structured and structured questions in the questionnaire was instrumental in the collection of comprehensive information from the field regarding the factors that might influence the Nurse turnover in public hospitals.

\section{Data Analysis Method}

Survey results were analysed quantitatively using SPSS software version 20.0. Descriptive and bivariate analyses were used to explore data, and multivariate analysis was performed. Bivariate analysis (pairwise correlation) was done to determine associations between intent to leave MTRH (nurse turnover) and other independent variables. At multivariable level, partial correlation was done. Multiple linear regression was done using the dependent and independent variables to quantify the effect of the independent variables on the dependent Variable. All statistical tests were done at $\alpha$ level of significance 0.05 and test statistics and corresponding $\mathrm{p}$-values reported Study findings were presented in Tables and graphs, to aid in the understanding of the information. On the other hand, qualitative data was grouped around the key themes surrounding the study, and was used to expound on the quantitative data.

\section{Results}

\section{Factors influencing Turn Over}

Responses of the participants were analyzed and presented as shown: 


\section{Working Conditions}

Table 1: Working conditions dissatisfaction

\begin{tabular}{|c|c|c|c|c|c|}
\hline & $\begin{array}{l}\text { Strongly } \\
\text { agree }\end{array}$ & Agree & Neutral & Disagree & $\begin{array}{l}\text { Strongly } \\
\text { disagree }\end{array}$ \\
\hline $\begin{array}{l}\text { 1) I am satisfied with my physical } \\
\text { environment }\end{array}$ & $37(13.7)$ & 123(54.7) & $48(17.8)$ & $42(15.6)$ & $19(7.1)$ \\
\hline $\begin{array}{l}\text { 2) I can easily move around my } \\
\text { work space }\end{array}$ & $53(19.6)$ & $129(47.8)$ & $42(15.6)$ & $37(13.7)$ & $9(3.3)$ \\
\hline $\begin{array}{l}\text { 3) if given a chance I would change } \\
\text { my work station }\end{array}$ & $65(24.5)$ & $73(27.6)$ & $38(14.3)$ & $58(21.9)$ & $31(11.7)$ \\
\hline $\begin{array}{l}\text { 4) I value friendship I have built } \\
\text { with colleagues over the years } \\
\text { 5) I am satisfied with adequate }\end{array}$ & $127(47.6)$ & $113(42.3)$ & $13(4.87)$ & $9(3.4)$ & $5(1.9)$ \\
\hline $\begin{array}{l}\text { social amenities available } \\
\text { 6) I have suffered from }\end{array}$ & $38(14.0)$ & $80(29.4)$ & $54(19.9)$ & $59(21.7)$ & $41(15.1)$ \\
\hline $\begin{array}{l}\text { preventable accidents in the } \\
\text { hospital }\end{array}$ & $38(14.2)$ & $45(16.8)$ & 40(14.9) & $87(32.5)$ & $58(21.6)$ \\
\hline $\begin{array}{l}\text { 7) I have suffered workplace } \\
\text { violence }\end{array}$ & $30(11.3)$ & 31(11.7) & $28(10.6)$ & $77(29.1)$ & $99(37.4)$ \\
\hline $\begin{array}{l}\text { 8) management carries routine } \\
\text { maintenance checks to ensure } \\
\text { safety }\end{array}$ & $38(14.1)$ & 111(41.1) & 51(18.9) & $45(16.7)$ & $25(9.3)$ \\
\hline $\begin{array}{l}\text { 9) staying in this hospital will } \\
\text { negatively affect my health in } \\
\text { long-run }\end{array}$ & 31(11.4) & $48(17.7)$ & $36(13.3)$ & $91(33.6)$ & $65(24.0)$ \\
\hline $\begin{array}{l}\text { 10) I wish management would } \\
\text { invest more money to look after } \\
\text { our welfare }\end{array}$ & 149(54.6) & $89(32.6)$ & $17(6.2)$ & $10(3.7)$ & $8(2.9)$ \\
\hline
\end{tabular}

Overall, the mean dissatisfaction level with working conditions at MTRH was 53.4 (SD11.5) percent, that is, 26.7(SD 5.7) over 50 total possible score.

\section{Inferential Statistic on Working Condition and its Influence on Nurses Turn Over}

Assuming the total/percentage intent to leave MTRH/nursing score represent the nurses' turnover probability, then we assess the factors that influence high score in intent to leave (high probability of nurses' turnover) by correlating this score with working conditions. 


\begin{tabular}{|c|c|c|}
\hline \multirow[b]{2}{*}{ Variable } & \multicolumn{2}{|c|}{$\begin{array}{l}\text { Pair } \\
\text { correlation }\end{array}$} \\
\hline & $r$ & p-value \\
\hline 1) I am satisfied with my physical Environment & 0.217 & $<0.001$ \\
\hline 2) I can easily move around my work space & 0.115 & 0.067 \\
\hline 3) if given a chance I would change my work station & -0.171 & 0.007 \\
\hline 4) I value friendship I have built with colleagues over the years & 0.089 & 0.160 \\
\hline 5) I am satisfied with adequate social amenities available & 0.323 & $<0.001$ \\
\hline 6) I have suffered from preventable accidents in the hospital & 0.171 & 0.006 \\
\hline 7) I have suffered workplace Violence & -0.266 & $<0.001$ \\
\hline 8) management carries routine maintenance checks to ensure safety & 0.330 & $<0.001$ \\
\hline 9) staying in this hospital will negatively affect my health in long-run & -0.339 & $<0.001$ \\
\hline $\begin{array}{l}\text { 10) I wish management would invest more money to look after our } \\
\text { welfare }\end{array}$ & -0.087 & 0.163 \\
\hline Overall & $r=.391$ & $p<0.001$ \\
\hline
\end{tabular}

Among the variables under the working conditions, almost all were significantly associated with nurses turn over. However, the strength of association deferred for example, those who disagreed with statement "staying in this hospital will negatively affect my health in long-run" had higher intent to leave MTRH with the strongest association ( $r=-.339)$. Followed with those who disagreed with the statement "management carries routine maintenance checks to ensure safety" ( $r=.0 .330)$. Disagreement with "I am satisfied with adequate social amenities available" was third in terms of strength of association $(r=.0 .323)$. The overall correlation showed that those who were dissatisfied with working conditions were more likely to have intent to leave MTRH $(r=.391, p<0.001)$.

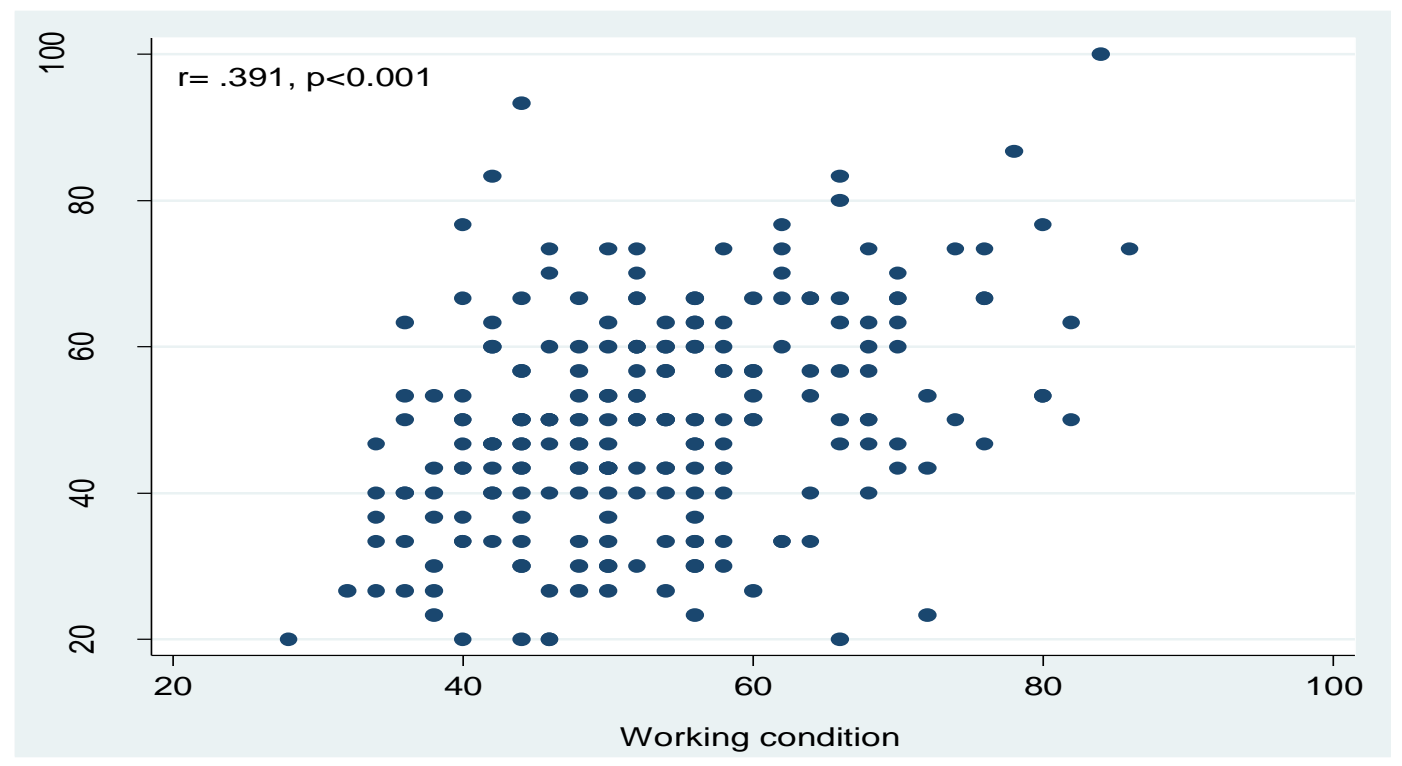

Figure 1: Influence of working conditions on nurses' turnover

The figure 4.1above shows the association between lack of satisfaction with working conditions and intent to leave MTRH/Nursing. The results show that there was a positive 
correlation between dissatisfaction level and the intent to leave MTRH. That is, those who felt dissatisfied with the working conditions were more likely to have intention to leave MTRH ( $r=$ $.391, p<0.001)$.

\section{Training and Development}

Table 3: Training and development dissatisfaction

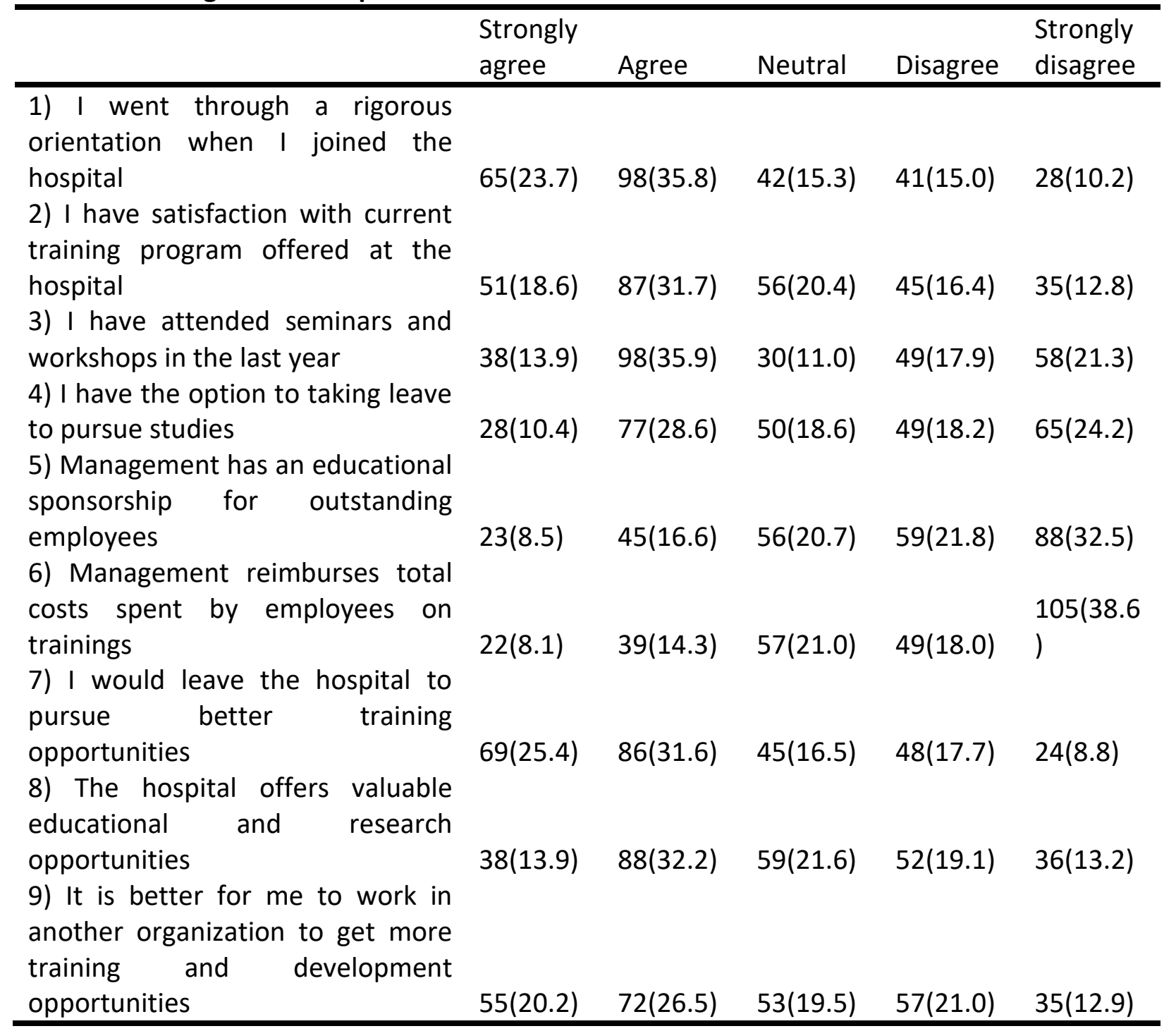

The questions above in Table 4.6 were directed at measuring the nurses' dissatisfaction level with training and development opportunities offered by MTRH. A score on 1 was allocated to strongly agree while strongly disagree was allocated a score of 5 . Question 7 was reversed to match the rest. There after a sum of these score that ranged from 9 to 45 was used to measure dissatisfaction level with training and development opportunities offered by MTRH. Overall, the dissatisfaction level with training and development opportunities offered by MTRH was 61.2 (SD 14.7) percent, that is, 27.6(SD 6.6) over 45 total possible score. 


\section{Inferential Statistics Influence of Training and Development on Nurses' Turnover}

Assuming the total/percentage intent to leave MTRH/nursing score represent the nurses' turnover probability, then we assess the factors that influence high score in intent to leave (high probability of nurses' turnover) by correlating this score with Training and development.

Table 4: Influence of training and development on nurses' turnover

\begin{tabular}{|c|c|c|}
\hline \multirow[b]{2}{*}{ Variable } & \multicolumn{2}{|c|}{ Pair wise correlation } \\
\hline & $r$ & p-value \\
\hline $\begin{array}{l}\text { 1) I went through a rigorous orientation } \\
\text { when I joined the hospital }\end{array}$ & 0.300 & $<0.001$ \\
\hline $\begin{array}{l}\text { 2) I have satisfaction with current } \\
\text { training program offered at the hospital }\end{array}$ & 0.305 & $<0.001$ \\
\hline $\begin{array}{l}\text { 3) I have attended seminars and } \\
\text { workshops in the last year }\end{array}$ & 0.177 & 0.004 \\
\hline $\begin{array}{l}\text { 4) I have the option to taking } \\
\text { leave to pursue studies }\end{array}$ & 0.256 & $<0.001$ \\
\hline $\begin{array}{l}\text { 5) Management has an educational sponsorship } \\
\text { for outstanding employees }\end{array}$ & 0.300 & $<0.001$ \\
\hline $\begin{array}{l}\text { 6) Management reimbursement total costs spent } \\
\text { by employees on trainings }\end{array}$ & 0.376 & $<0.001$ \\
\hline $\begin{array}{l}\text { 7) I would leave the hospital to pursue } \\
\text { better training opportunities }\end{array}$ & 0.244 & $<0.001$ \\
\hline $\begin{array}{l}\text { 8) The Hospital offer valuable educational } \\
\text { and research opportunities }\end{array}$ & 0.409 & $<0.001$ \\
\hline $\begin{array}{l}\text { 9) It's better for me to work in another } \\
\text { org to get more training and development opportunities }\end{array}$ & -0.268 & $<0.001$ \\
\hline Overall & $r=.398$ & $p<0.001$ \\
\hline
\end{tabular}

Majority of the parameters in this category (training and development) had stronger association with the outcome variable and all were significant. Those who disagreed with the statement "the hospital offers valuable educational and research opportunities" were more likely to have intent to leave MTRH with the highest correlation score ( $r=.409)$. Followed by those who disagreed with the statement "management reimbursement of total costs spent by employees on trainings ( $r=.376)$. 


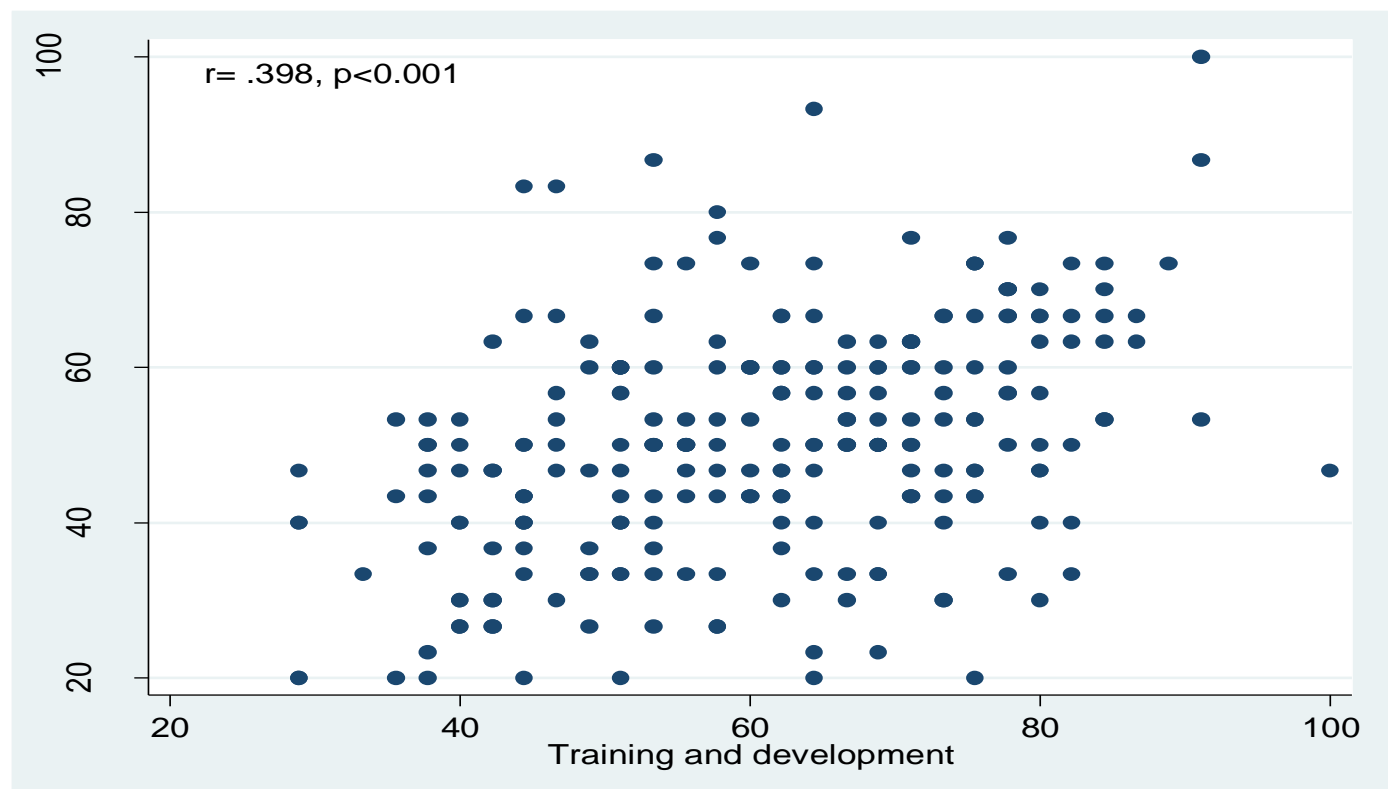

Figure 2: Influence of training and development on nurses' turnover

There was a significant association between lack of satisfaction with training/development policies and intent to leave MTRH/Nursing. The results show a positive correlation between dissatisfaction level and the intent to leave MTRH. That is, those who felt dissatisfied with the training and development policies were more likely to have intention to leave MTRH ( $r=.398$, $\mathrm{p}<0.001)$.

Pay and Benefits

Table 5: Pay and benefits dissatisfaction

\begin{tabular}{|c|c|c|c|c|c|}
\hline & $\begin{array}{l}\text { Strongly } \\
\text { agree }\end{array}$ & Agree & Neutral & Disagree & $\begin{array}{l}\text { Strongly } \\
\text { disagree }\end{array}$ \\
\hline $\begin{array}{l}\text { 1) Hospital has competitive pay } \\
\text { structure compared with the } \\
\text { industry }\end{array}$ & $57(21.3)$ & $102(38.1)$ & $50(18.7)$ & $39(14.6)$ & $20(7.5)$ \\
\hline $\begin{array}{l}\text { 2) I am willing to work overtime to } \\
\text { help org meet its goals } \\
\text { 3) my compensation allows }\end{array}$ & $62(22.9)$ & $95(35.1)$ & $48(17.7)$ & $40(14.8)$ & 26(9.6) \\
\hline comfortable life & $41(15.0)$ & $71(26.0)$ & $57(20.9)$ & $57(20.9)$ & $47(17.2)$ \\
\hline $\begin{array}{l}\text { 4) I feel salary structure is fair and } \\
\text { hold equity with my co-workers } \\
\text { 5) other org provides more } \\
\text { comprehensive benefits than my }\end{array}$ & $28(10.3)$ & $82(30.2)$ & $55(20.2)$ & $56(20.6)$ & $51(18.8)$ \\
\hline $\begin{array}{l}\text { comprehensive benefits than my } \\
\text { organization } \\
\text { 6) The organization has timely and }\end{array}$ & $56(20.6)$ & $73(26.8)$ & $72(26.5)$ & 48(17.7) & $23(8.5)$ \\
\hline $\begin{array}{l}\text { consistent payment plan for all staff } \\
\text { 7) I would leave the hospital for }\end{array}$ & $61(22.3)$ & $91(33.3)$ & $39(14.3)$ & $48(17.6)$ & $34(12.5)$ \\
\hline $\begin{array}{l}\text { better pay elsewhere } \\
\text { 8) The hospital has comprehensive }\end{array}$ & $74(27.2)$ & $69(25.4)$ & $56(20.6)$ & $31(11.4)$ & $42(15.4)$ \\
\hline medical cover & $58(21.4)$ & $105(38.8)$ & $34(12.6)$ & $36(13.3)$ & $38(14.0)$ \\
\hline
\end{tabular}


The questions above in Table 4.6 were directed at measuring the nurses' dissatisfaction level with pay and benefits offered by MTRH. A score on 1 was allocated to strongly agree while strongly disagree was allocated a score of 5 . Questions 5, and 7 were reversed to match the rest. There after a sum of these score that ranged from 8 to 40 was used to measure dissatisfaction level with pay and benefits offered by MTRH. Overall, the mean dissatisfaction level with pay and benefits offered by MTRH was 57.2 (SD15.2) percent, that is, 22.9(SD 6.1) over 40 total possible score.

\section{Inferential Statistics Influence of pay and benefits on nurses' turnover}

Assuming the total/percentage intent to leave MTRH/nursing score represent the nurses' turnover probability, then we assess the factors that influence high score in intent to leave (high probability of nurses' turnover) by correlating this score with pay and benefits.

Table 6: Influence of pay and benefits on nurses' turnover

\begin{tabular}{|c|c|c|}
\hline \multirow[b]{2}{*}{ Variable } & \multicolumn{2}{|c|}{$\begin{array}{l}\text { Pair wise } \\
\text { correlation }\end{array}$} \\
\hline & $r$ & p-value \\
\hline & 0.33 & $<0.001$ \\
\hline \multirow[t]{2}{*}{ 1) Hospital has competitive pay structure compared with the industry } & 3 & \\
\hline & 0.35 & $<0.001$ \\
\hline \multirow[t]{2}{*}{ 2) I am willing to work overtime to help org meet its goals } & 9 & \\
\hline & 0.32 & $<0.001$ \\
\hline \multirow[t]{2}{*}{ 3) my compensation allows comfortable life } & 0 & \\
\hline & 0.37 & $<0.001$ \\
\hline \multirow[t]{3}{*}{ 4) I feel salary structure is fair and hold equity with my co-workers } & 3 & \\
\hline & - & 0.002 \\
\hline & 0.19 & \\
\hline \multirow[t]{2}{*}{ 5) other organizations provide more comprehensive benefits than my org } & 2 & \\
\hline & 0.38 & $<0.001$ \\
\hline \multirow[t]{3}{*}{ 6) org has timely and consistent payment plan for all staff } & 7 & \\
\hline & - & $<0.001$ \\
\hline & 0.25 & \\
\hline \multirow[t]{2}{*}{ 7) I would leave the hospital for better pay elsewhere } & 2 & \\
\hline & 0.25 & $<0.001$ \\
\hline \multirow[t]{2}{*}{ 8) Hospital has comprehensive medical cover } & 4 & \\
\hline & $r=$ & $p<0.00$ \\
\hline Overall & .513 & 1 \\
\hline
\end{tabular}

Answers to all the questions in this category of pay and benefits were significantly associated with the intent to leave MTRH with strong associations compared to the other three categories under investigation. Those with weaker associations included disagreement with "other organizations provide more comprehensive benefits than my organization ( $r=-.192)$ " "I would leave the hospital for better pay elsewhere $(p=-.252)$ " and "the hospital has comprehensive medical cover $(p=.254)$ ". The strongest association was seen in those who disagreed with statement "The organization has timely and consistent payment plan for all 
staff $(r=.387)$ " where those who disagreed with the statement were had higher intentions to leave MTRH.

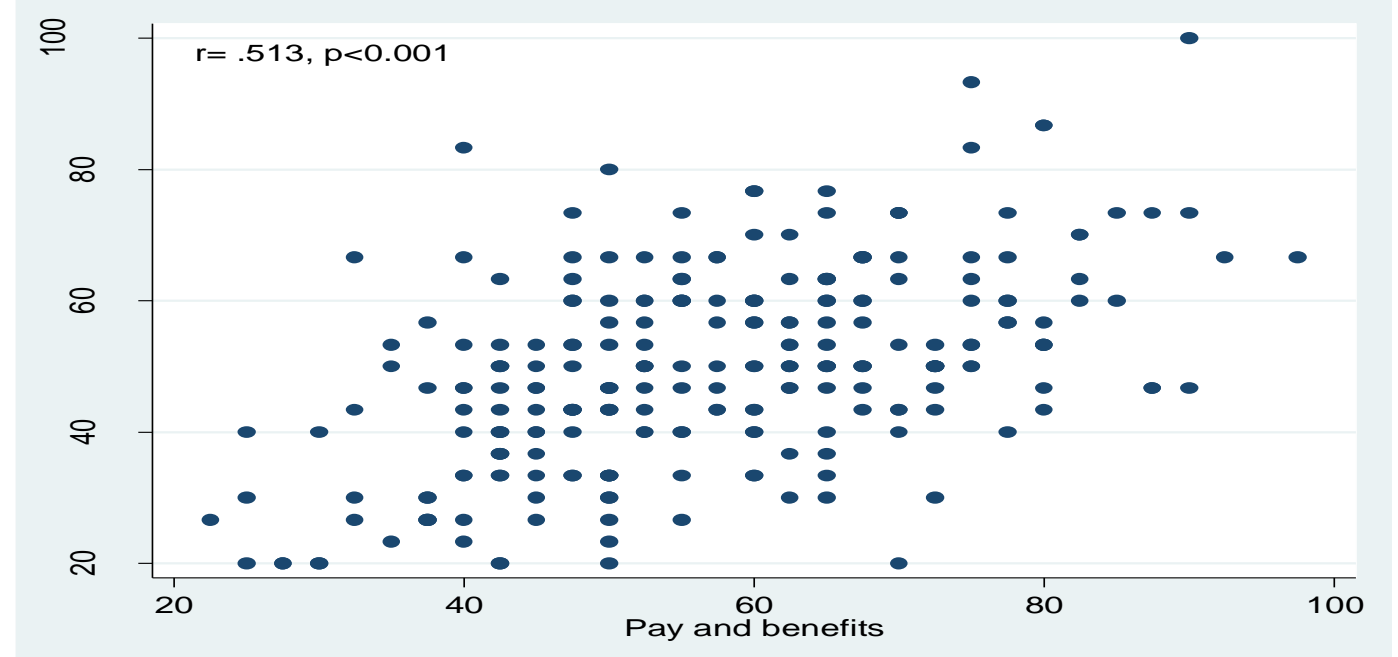

Figure 3: Influence of pay and benefits on nurses' turnover

The results in Figure 4.3 shows a positive correlation between pay and benefits dissatisfaction level and the intent to leave MTRH. That is, those who felt dissatisfied with pay and benefits were more likely to have intention to leave MTRH $(r=.513, p<0.001)$.

\section{Management Support}

Table 7: Management support dissatisfaction

\begin{tabular}{|c|c|c|c|c|c|}
\hline & $\begin{array}{l}\text { Strongly } \\
\text { agree }\end{array}$ & Agree & Neutral & Disagree & $\begin{array}{l}\text { Strongly } \\
\text { disagree }\end{array}$ \\
\hline $\begin{array}{l}\text { 1) I have good relationship with my } \\
\text { manager } \\
\text { 2) I am proud to work with my }\end{array}$ & $110(40.1)$ & $112(40.9)$ & $27(9.9)$ & $16(5.8)$ & $9(3.3)$ \\
\hline supervisor's leadership & $101(37)$ & $125(45.8)$ & $23(8.4)$ & $14(5.1)$ & $10(3.7)$ \\
\hline 3) I disagree with appraisal policies & $32(12.0)$ & $72(27.0)$ & $71(26.5)$ & $54(20.2)$ & $38(14.2)$ \\
\hline $\begin{array}{l}\text { 4) I know other organizations that treat } \\
\text { their employees more well than this } \\
\text { hospital' }\end{array}$ & $66(24.4)$ & $71(26.3)$ & $62(23.0)$ & $36(13.3)$ & $35(13.0)$ \\
\hline $\begin{array}{l}\text { 5) I would consider leaving to another } \\
\text { org that would appreciate my skills } \\
\text { better }\end{array}$ & $61(22.7)$ & $59(21.9)$ & $65(24.2)$ & $43(16.0)$ & $41(15.2)$ \\
\hline $\begin{array}{l}\text { 6) I am actively engaged in decision } \\
\text { making process }\end{array}$ & $28(10.3)$ & $83(30.5)$ & $65(23.9)$ & $58(21.3)$ & $38(14.0)$ \\
\hline $\begin{array}{l}\text { 7) I have unreasonable workload } \\
\text { 8) I would recommend my supervisor to }\end{array}$ & $81(30.3)$ & $67(25.1)$ & $54(20.2)$ & $43(16.1)$ & $22(8.2)$ \\
\hline everybody & $64(23.5)$ & $109(40.1)$ & $69(25.4)$ & $17(6.3)$ & $13(4.8)$ \\
\hline $\begin{array}{l}\text { 9) lack of clear org goals cause constant } \\
\text { friction with management }\end{array}$ & $59(21.7)$ & $97(35.7)$ & $46(16.9)$ & 49(18.0) & $21(7.7)$ \\
\hline
\end{tabular}

The questions above in Table 10 were directed at measuring the nurses' dissatisfaction level with management support at MTRH. A score on 1 was allocated to strongly agree while 
strongly disagree was allocated a score of 5 . Questions 3, 4, 5, 7, and 9 were reversed to match the rest. There after a sum of these score that ranged from 9 to 45 was used to measure dissatisfaction level with management support at MTRH. Overall, the mean dissatisfaction level with management support at MTRH was 56.8 (SD12.3) percent, that is, 25.6(SD 5.5) over 45 total possible score.

\section{Inferential Statics Influence of Management Support on Nurses' Turnover}

Assuming the total/percentage intent to leave MTRH/nursing score represent the nurses' turnover probability, then we assess the factors that influence high score in intent to leave (high probability of nurses' turnover) by correlating this score with management support.

Table 8: Influence of management support on nurses' turnover

\begin{tabular}{lll}
\hline & \multicolumn{2}{c}{ Pairwise correlation } \\
Variable & $r$ & $p$-value \\
\hline $\begin{array}{l}\text { 1) I have good relationship with } \\
\text { my manager }\end{array}$ & 0.192 & 0.002 \\
2) I am proud to work with my supervisor's leadership & 0.288 & $<0.001$ \\
3) I disagree with appraisal policies & -0.124 & 0.049 \\
4) I know other organization that treat their employees more & -0.340 & $<0.001$ \\
well than this hospital' & & \\
5) I would consider leaving to another & -0.328 & $<0.001$ \\
org that would appreciate my skills better & & \\
6) I am actively engaged in decision & 0.311 & $<0.001$ \\
making process & & \\
7) I have unreasonable workload & -0.156 & 0.013 \\
8) I would recommend my supervisor & 0.319 & $<0.001$ \\
to everybody & & \\
9) lack of clear org goals cause constant & -0.140 & 0.025 \\
friction with management & & \\
Overall & $\mathrm{r}=.493$ & $\mathrm{p}<0.001$ \\
\hline
\end{tabular}

The strongest association was seen in those who disagreed with the statement "I know other organizations that treat their employees better than this hospital" ( $r=-.340)$ which means that they were more unlikely to leave MTRH. Disagreement with "I would consider leaving to another organization that would appreciate my skills better" was second in terms of strength of association ( $r=-.328$ ) where those who disagreed with the statement were unlikely to have intent to leave MTRH. Disagreement with the statements "I would recommend my supervisor to everybody" and "I am actively engaged in decision making process" come $3^{\text {rd }}$ and $4^{\text {th }}$ respectively where those who disagreed with the statements were likely to have intent to leave MTRH. 


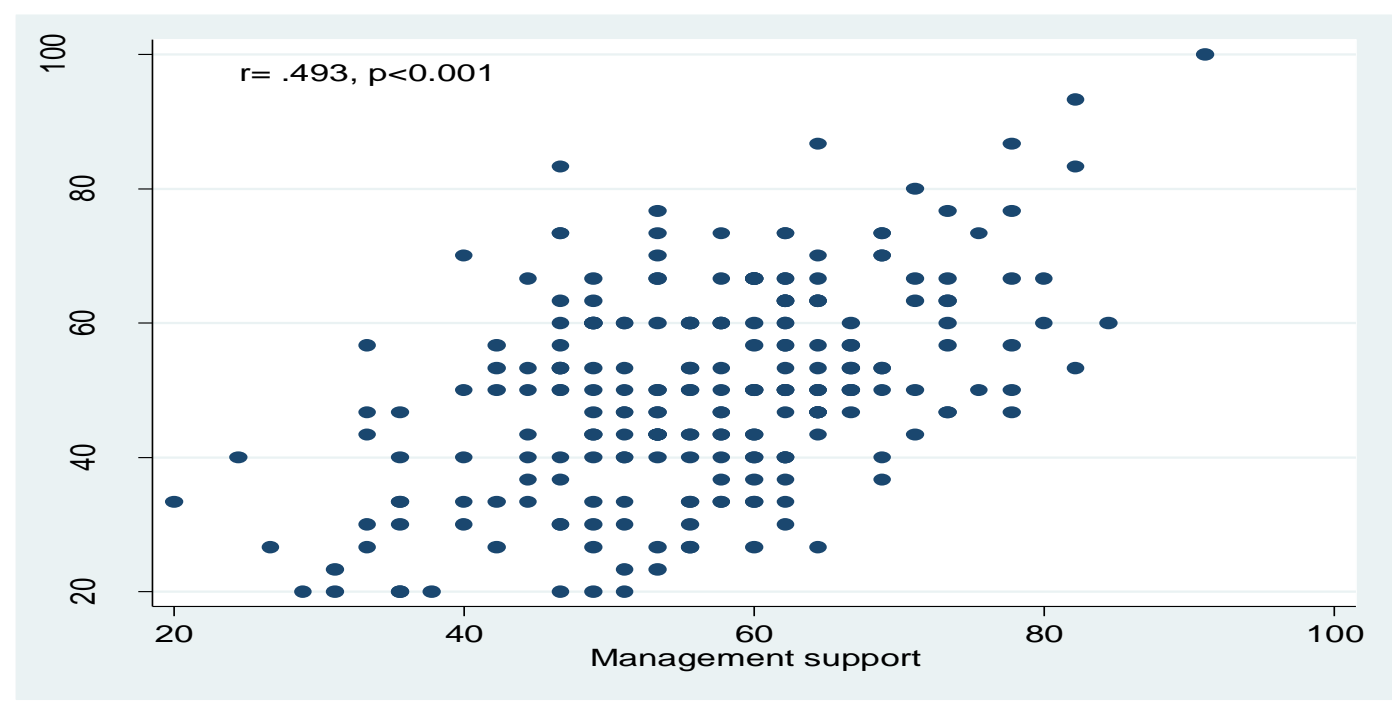

Figure 9: Influence of management support on nurses' turnover

The figure 4.4 above shows the association between lack of satisfaction with support given by management and intent to leave MTRH/Nursing. The results show that there was a positive correlation between dissatisfaction level and the intent to leave MTRH. That is, those who felt dissatisfied with the way management support the staff, were more likely to have intention to leave MTRH ( $r=.493, p<0.001)$.

\section{Intent to Leave}

Table 10: Intent to leave MTRH/nursing

\begin{tabular}{llllll}
\hline & $\begin{array}{l}\text { Strongly } \\
\text { agree }\end{array}$ & Agree & Neutral & Disagree & $\begin{array}{l}\text { Strongly } \\
\text { disagree }\end{array}$ \\
\hline $\begin{array}{l}\text { 1) I would prefer to work with } \\
\text { MTRH even if given same salary } \\
\text { elsewhere }\end{array}$ & $88(32.5)$ & $76(28.0)$ & $47(17.3)$ & $30(11.1)$ & $30(11.1)$ \\
$\begin{array}{l}\text { 2) Given better remuneration } \\
\text { elsewhere I would stay in MTRH }\end{array}$ & $55(20.3)$ & $52(19.2)$ & $45(16.6)$ & $66(24.4)$ & $53(19.6)$ \\
$\begin{array}{l}\text { 3) I consider myself a nurse by } \\
\text { choice }\end{array}$ & $145(54.9)$ & $74(28.0)$ & $23(8.7)$ & $6(2.3)$ & $16(6.1)$ \\
$\begin{array}{l}\text { 4) Given opportunity I would } \\
\text { change my career }\end{array}$ & $37(13.6)$ & $48(17.7)$ & $37(13.1)$ & $53(19.6)$ & $96(35.4)$ \\
$\begin{array}{l}\text { 5) Overall, I have job satisfaction } \\
\text { at MTRH }\end{array}$ & $48(18.1)$ & $92(34.7)$ & $62(23.4)$ & $36(13.6)$ & $27(10.2)$ \\
$\begin{array}{l}\text { 6) I do not have plans to leave the } \\
\text { organization given better }\end{array}$ & & & & & \\
opportunity & $71(26.5)$ & $59(22.0)$ & $54(20.1)$ & $39(14.6)$ & $45(16.8)$ \\
\hline
\end{tabular}

Table 4.12 above shows the response of respondents in regard to intent to leave MTRH for a better employer. To have a clear and objective measurement of the intent to leave MTRH, using all the six questions, a score was created where strongly agree was given a score of 1 while strongly disagree was given a score of 5 . However, question 4 "given opportunity 1 would change my career" was reversed to match the rest. There after a sum of these score that ranged from 6 to 30 was used to measure the intent to leave MTRH/nursing. The intent 
to leave MTRH/nursing for a better option was rated on average at $50 \%$ overall (SD15.1), that is, 15.0 (SD 4.5) over 30 total possible score.

\section{Discussion}

The study sought to examine the factors associated with nurses' turnover in public hospitals. Working conditions were evaluated in terms of physical environment, resource adequacy, and behavioural aspects of the hospital. There was weak correlation between nurse turnover and working conditions and the relationship between the two variables were insignificant. These findings are inconsistent with previous studies done on the topic that established a significant positive relationship between employee turnover and general working conditions. The need to understand the impact of working conditions and nurse turnover has attracted a lot of attention over the years. Physical working conditions affecting nurse turnover include odour, noise, work space, cleanliness, design, and colour (Applebaum et al., 2010). Our study found out that nurses are keen on the physical characteristics of the working environment particularly aspects that may lead to physical injuries. Ensuring employees safety is an important aspect and creating a good working environment. However, poor design of the workplace, lack of adequate space in the working area, and lighting problems can contribute to preventable accidents. The respondents indicated that, the management rarely conducted safety audits in the workplace despite the fact that nurses spent a significant portion of their time at the working station (Horiguchi et al., 2015). The hospital's safety procedures are wanting because many respondents indicated they had suffered from preventable work injuries. Moreover, safety measures should be established for both physical and behavioural facets of the organization. Also, the respondents valued the availability of social amenities that influences how they spent their free time and interacted with co-workers to form relationships. This concurs with the fact that friendships and social connections with others are highly valued and are likely to affect employees' intentions to leave the hospital. However, the relationships are influenced by employees' attitude towards others that determines the formation of strong bonds among the employees and group cohesion and this in turn influences the rate of turnover (Momanyi \& Kaimenyi, 2015).

Nurses encounter many challenges in their line of work that may be attributable to many factors such as high disease burdens, shortage of workers, and inadequate resources at the institution. Moreover, nurses are subjected to verbatim abuses by patients and family members in relation to their work. The indicators of a Nurse poor health include high burnout, stress, and anxiety that often pushes them to the limit. Although many nurses may not detect when their health is negatively affected by the working conditions, they react by leaving the organization. Undoubtedly, this problem is more pronounced in Kenya and other African countries due to the severe shortage of qualified nurses in the country and financial problems that makes the purchase of adequate medical supplies a big challenge (Rachiotis et al., 2014). In the research it comes out strongly that management has a key role in creating a good working environment, thus organizational leaders can prevent nurse turnover by taking the right steps.

Adequate and stable nurse staffing and managerial support are essential to promote highquality patient care, job satisfaction, minimal job stress and, ultimately, address nurse turnover in healthcare settings. It is critical for managers to understand how staff nurses perceive the work environment as these perceptions may affect nurses' intention to leave the organization. Creating and fostering environments that support healthcare professionals and nurses in particular will help to retain existing nurse and attract front-line staff. Supportive 
environments allow staff and to receive adequate orientation, ongoing mentorship and sufficient human and fiscal resources to provide quality patient care.

\section{Conclusion}

Management support is a critical determination of labour turnover in the health sector. Nurses need to feel valued and respected by their immediate supervisors. Nurses encounter many challenges at work as discussed above that may prompt them to look for better employment opportunities, but knowing they have inspired confidence in their managers can make all the difference. It is noteworthy that relationship between employees and supervisors develop gradually, and the conduct of both parties influences the strength of the connection. Workers engagement in decision making process provides insight about the type of leadership style practiced in an organization. Autocratic leadership style, decision making is restricted to few individuals in the organization. Democratic leadership allows employs to have a say in major decisions affecting their welfare, while laissez faire style the employees have absolute control over their work. From the research findings, 60\% indicated the organization has democratic leadership but the degree of nurse participation in the decisionmaking process differs between departments. Managers show their support by upholding several values and practices. These include fairness, justice, respect appreciation, honesty, and open communication with the nurses. Moreover, managers should show personal concern for subordinates; hence they refrain from allocating very heavy workloads in spite of the amount of work pressure. Besides, supportive managers learn how to incorporate employees' viewpoints in developing the overall vision for their respective departments.

\section{Theoretical and Contextual Contribution of the Study}

Our study findings uncovered new theoretical insights in relation to the Unfolding Theory of Turnover. The classification of employees into the various pathways of the Unfolding Theory can be used by the hospital management to develop effective retention strategies. Retention strategies can also be tailored based on the most prominent pathway in the hospital setup. For those not leaving due to a shock, but instead due to mounting dissatisfaction, an organization can be sure to conduct periodic monitoring of satisfaction levels and implement strategies to increase satisfaction. This can include things such as holding one-on-one meetings between employees and their manager to address any current problems or allowing for a flexible work schedule. If the majority of employees are leaving because of unsolicited job offers, organizations can begin to attack the problem directly, perhaps by adjusting compensation to remain competitive or being prepared to make counter offers to the employee. In order to encourage healthcare professional retention, the hospital management should develop an overall staff retention plan which addresses the work environment and internal motivating factors.

On a contextual and practical level, these findings highlight the needs for intervention at the individual, manager and organizational level. At the individual level, it would be important for nurses to identify effective coping strategies to deal with work related stress. Managers and senior leaders in organizations also need to consider the perceived job stress of their staff. This may involve finding ways to assist the work-life balance of their employees, for example, creating the option for self-scheduling on the unit. Other ways to alleviate perceived job stress is to have participative leadership management where employers check in regularly with employees to ask about the workload and ask about improving processes on the unit. The hospital management should improve on nurses' recognition by offering gratitude for job well 
done and publicly celebrate nurses who go out of their way and do their work well. The human resource department should put in place a growth and development policy which ensures that there is fairness in the way promotions are offered and training needs of nurses are addressed. Hospital managers should also involve nurses in the creation of duty roster and in the organization of shifts. Hospital administrators should maximize effort in the handling of healthcare workers and motivate dissatisfied employees.

\section{Study Limitation}

This study was not without limitation. Caution should be maintained when interpreting and generalizing study findings in light of the limitations identified. First, this study was conducted within one National referral hospital based in the Western Kenya region in Uasin Gishu county, one of the 47 counties in Kenya. The exclusion of nurses from other referral hospitals may affect the generalizability of the findings. Therefore, it is recommended that future studies explore all the referral hospitals in the country.

\section{References}

Ahmed, S., \& Waqas, H. (2017). Occupational injuries and employees turnover intention: a moderating effect of safety culture. Pakistan Business Review, 18(4), 960-977.

Aiken, L. H., Clarke, S. P., Sloane, D. M., \& Sochalski, J. (2001). Cause for concern: nurses' reports of hospital care in five countries. LDI Issue Brief, 6(8), 1-4.

Ankomah, S. E., Kumah, E., \& Karikari, A. K. (2016). Health Worker Motivation in Ghana: the role of non-financial incentives. A case study of Accident and Emergency Department of Komfo Anokye Teaching Hospital. International Journal of Biosciences, Healthcare Technology and Management, 6(4), 34.

Anyangwe, S. C., \& Mtonga, C. (2007). Inequities in the global health workforce: the greatest impediment to health in sub-Saharan Africa. International Journal of Environmental Research and Public Health, 4(2), 93-100.

Applebaum, D., Fowler, S., Fiedler, N., Osinubi, O., \& Robson, M. (2010). The impact of environmental factors on nursing stress, job satisfaction, and turnover intention. The Journal of nursing administration, 40, 323.

Beach, L. R. (1998). Image theory: Theoretical and empirical foundations: Routledge.

Cartledge, S. (2001). Factors influencing the turnover of intensive care nurses. Intensive and Critical Care Nursing, 17(6), 348-355.

Chankova, S., Muchiri, S., \& Kombe, G. (2009). Health workforce attrition in the public sector in Kenya: a look at the reasons. Human Resources for Health, 7(1), 58.

Chen, L., Evans, T., Anand, S., Boufford, J. I., Brown, H., Chowdhury, M., . . Elzinga, G. (2004). Human resources for health: overcoming the crisis. The Lancet, 364(9449), 1984-1990.

Coomber, B., \& Barriball, K. L. (2007). Impact of job satisfaction components on intent to leave and turnover for hospital-based nurses: a review of the research literature. International journal of nursing studies, 44(2), 297-314.

Cowin, L. (2002). The effects of nurses' job satisfaction on retention: an Australian perspective. JONA: The Journal of Nursing Administration, 32(5), 283-291.

Deighan, K. (2016). Managerial strategies for reducing employee turnover in the workplace.

Dewanto, A., \& Wardhani, V. (2018). Nurse turnover and perceived causes and consequences: A preliminary study at private hospitals in Indonesia. BMC nursing, 17(2), 52.

Dovlo, D. (2005). Wastage in the health workforce: some perspectives from African countries. Human Resources for Health, 3(1), 6. 
Estryn-Béhar, M., Nézet, O. I., Van der Heijden, B. I., Ogiñska, H., Camerino, D., Conway, P. M., ... Hasselhorn, H.-M. (2007). Inadequate teamwork and burnoutas predictors of intent to leave nursing according to seniority. Stability of associations in a one-year intervalin the European NEXT Study.

Fasanya, B. K., \& Dada, E. A. (2016). Workplace violence and safety issues in long-term medical care facilities: nurses' perspectives. Safety and health at work, 7(2), 97-101.

Gerein, N., Green, A., \& Pearson, S. (2006). The implications of shortages of health professionals for maternal health in sub-Saharan Africa. Reproductive health matters, 14(27), 40-50.

Haider, M., Aamir, A., Hamid, A., \& Hashim, M. (2015). A literature analysis on the importance of non-financial rewards for employees' job satisfaction. Abasyn Journal of Social Sciences, 8(2), 341-354.

Horiguchi, M., Shudo, E., Sato, K., Nakamura, M., Sai, W., \& Ohinata, T. (2015). Nurse odor perception in various Japanese hospital settings. International Journal of Nursing Sciences, 2(4), 355-360.

Hung, M. S., \& Lam, S. K. (2020). Antecedents and Contextual Factors Affecting Occupational Turnover among Registered Nurses in Public Hospitals in Hong Kong: A Qualitative Descriptive Study. International Journal of Environmental Research and Public Health, $17(11), 3834$.

Jagun, V. (2015). An Investigation into the High Turnover of Employees within the Irish Hospitality Sector, Identifying What Methods of Retention Should Be Adopted. Dublin, National College of Ireland,

Jones, C. B. (2004). The costs of nurse turnover: part 1: an economic perspective. JONA: The Journal of Nursing Administration, 34(12), 562-570.

Lee, T. W., \& Mitchell, T. R. (1994). An alternative approach: The unfolding model of voluntary employee turnover. Academy of management review, 19(1), 51-89.

Liese, B., \& Dussault, G. (2004). The state of the health workforce in sub-Saharan Africa: evidence of crisis and analysis of contributing factors. Retrieved from

Madanayake, O. C. (2014). Managerial Roles in Top Management Support for Information Technology and Systems Projects.

McGuire, D., \& McLaren, L. (2009). The impact of physical environment on employee commitment in call centres. Team Performance Management: An International Journal.

McHugh, M. D., \& Ma, C. (2014). Wage, work environment, and staffing: effects on nurse outcomes. Policy, Politics, \& Nursing Practice, 15(3-4), 72-80.

Ministry of Health. (2018). Kenya HIV estimates: report 2018. In: National AIDS Control Council Nairobi.

Momanyi, N. B., \& Kaimenyi, C. K. (2015). An investigation into factors causing high nurse turnover in mission hospitals in Kenya: A case for Pcea Chogoria Hospital. International Journal of Academic Research in Business and Social Sciences, 5(3), 55.

Morrell, K., Loan-Clarke, J., Arnold, J., \& Wilkinson, A. (2008). Mapping the decision to quit: A refinement and test of the unfolding model of voluntary turnover. Applied Psychology, 57(1), 128-150.

Naicker, S., Plange-Rhule, J., Tutt, R. C., \& Eastwood, J. B. (2009). Shortage of healthcare workers in developing countries--Africa. Ethnicity \& disease, 19(1), 60. 
Nguyen, L., Ropers, S., Nderitu, E., Zuyderduin, A., Luboga, S., \& Hagopian, A. (2008). Intent to migrate among nursing students in Uganda: measures of the brain drain in the next generation of health professionals. Human Resources for Health, 6(1), 5.

Onyango, H. (2016). The influence of motivation and work environment on nurse retention: a case of Shalom Hospitals. Strathmore University,

Rachiotis, G., Kourousis, C., Kamilaraki, M., Symvoulakis, E. K., Dounias, G., \& Hadjichristodoulou, C. (2014). Medical supplies shortages and burnout among greek health care workers during economic crisis: a pilot study. International journal of medical sciences, 11(5), 442.

Shader, K., Broome, M. E., Broome, C. D., West, M. E., \& Nash, M. (2001). Factors influencing satisfaction and anticipated turnover for nurses in an academic medical center. JONA: The Journal of Nursing Administration, 31(4), 210-216.

Shields, M. A., \& Ward, M. (2001). Improving nurse retention in the National Health Service in England: the impact of job satisfaction on intentions to quit. Journal of health economics, 20(5), 677-701.

Skefales, A., Plakas, S., Fouka, G., Goni, M., Vassiliadou, M., \& Bergiannaki, J.-D. (2014). Burnout and Its Association with working conditions among Greek hospital Nurses in a Time of Financial Crisis. Open Journal of Nursing, 2014.

Sousa, A., Tandon, A., Dal Poz, M. R., Prasad, A., \& Evans, D. B. (2006). Measuring the efficiency of human resources for health for attaining health outcomes across subnational units in Brazil. Background paper prepared for the World Health Report.

Tshitangano, T. G. (2013). Factors that contribute to public sector nurses' turnover in Limpopo province of South Africa. African Journal of Primary Health Care \& Family Medicine, $5(1)$.

World Health Organization. (2019). World health statistics overview 2019: monitoring health for the SDGs, sustainable development goals. Retrieved from 